\title{
Pengembangan E-Modul Matakuliah Masalah Nilai Awal Syarat Batas Berbasis Experiential Learning untuk Meningkatkan Kemampuan Penalaran Matematis Mahasiswa
}

\author{
Elfis Suanto ${ }^{1}$, Armis $^{2}$, Syarifah Nur Siregar ${ }^{3}$ \\ ${ }^{1,2,3}$ Program Studi Pendidikan Matematika, Fakultas Keguruan Ilmu Pendidikan, Universitas Riau \\ Jl. Bina Widya Simpang Baru, Pekanbaru \\ elfis.suanto@lecturer.unri.ac.id
}

\begin{abstract}
Mathematical reasoning is a mathematical ability that is necessary and important for Mathematics Education students. Mathematical reasoning is a mathematical thinking process in obtaining mathematical conclusions based on relevant facts, concepts, and methods. On the other hand, the facts show that the mathematical reasoning ability of students of the Mathematics Education study program at FKIP UNRI is not very good or can be said to be low, especially in the subject of Initial Value Problems and Boundary Conditions (MNASB). This is indicated by the fact that student learning outcomes have been low in these subjects in the last three years. Then, in connection with the current COVID-19 outbreak, including in Pekanbaru, Riau, which forced face-to-face educational institutions to transform into distance education institutions with an online learning system. This research is a type of research development study with two stages, namely the stages of preliminary evaluation and formative evaluation. The final goal of this research is to produce a product such as E-Module is based on an experiential learning approach that has the potential to improve students' mathematical reasoning abilities. The results of the study indicate that the developed E-Module has met the aspects of validity and practicality and has the potential to develop students' mathematical reasoning abilities. The e-Module developed is expected to serve as an example and guide for lecturers, students and higher education institutions in conducting mathematics learning oriented towards mathematical reasoning abilities in accordance with the demands of the curriculum. The form of questions in the MNASB E-Module that are applied in the learning process is in the form of non-routine questions so that they can hone students' mathematical reasoning skills.
\end{abstract}

Keywords: E-Modul, initial value problem and boundary conditions; mathematical reasoning ability

\begin{abstract}
Abstrak
Penalaran matematis merupakan salah satu kemampuan matematis yang perlu dan penting dimiliki oleh mahasiswa Pendidikan Matematika. Penalaran matematis merupakan proses berpikir matematik dalam memperoleh kesimpulan matematis berdasarkan fakta-fakta, konsep dan metode yang relevan. Dilain pihak, fakta menunjukkan bahwa kemampuan penalaran matematis mahasiswa program studi Pendidikan Matematika FKIP UNRI belum terlalu baik atau dapat dikatakan rendah terutama pada matakuliah Masalah Nilai Awal dan Syarat Batas (MNASB). Hal ini ditunjukkan oleh fakta rendahnya capaian hasil belajar mahasiswa pada matakuliah tersebut dalam tiga tahun terakhir. Kemudian, berhubung dengan wabah COVID-19 yang terjadi saat ini termasuk di Pekanbaru, Riau yang memaksa institusi-institusi pendidikan tatap muka untuk bertransformasi menjadi institusi pendidikan jarak jauh dengan sistim pembelajaran secara daring. Penelitian ini merupakan penelitian pengembangan tipe development studies dengan dua tahapan yaitu tahapan preliminary evaluation dan formative evaluation. Tujuan akhir penelitian ini adalah menghasilkan produk berupa E-Modul berbasis pendekatan experiential learning yang potensial untuk meningkatkan kemampuan penalaran matematis mahasiswa. Hasil penelitian menunjukkan bahwa E-Modul yang dikembangkan sudah memenuhi apek validitas dan praktikalitas serta potensial untuk mengembangkan kemampuan penalaran matematis mahasiswa. E-Modul yang dikembangkan ini diharapkan sebagai contoh dan pedoman oleh dosen, mahasiswa dan institusi pendidikan tinggi dalam menyelenggarakan pembelajaran matematika yang berorientasi kemampuan penalaran matematis sesuai dengan tuntutan kurikulum. Bentuk soal pada E-Modul matakuliah MNASB yang diterapkan dalam proses pembelajaran berupa soal-soal non rutin sehingga dapat mengasah kemampuan penalaran matematis mahasiswa.
\end{abstract}

Kata kunci: E-Modul, masalah nilai awal syarat batas, kemampuan penalaran matematis

Copyright (c) 2021 Elfis Suanto, Armis, Syarifah Nur Siregar

$\triangle$ Corresponding author: Elfis Suanto

Email Address: elfis.suanto@lecturer.unri.ac.id (Jl. Bina Widya Simpang Baru, Pekanbaru)

Received 06 October 2021, Accepted 06 December 2021, Published 01 January 2022 


\section{PENDAHULUAN}

Penalaran matematis merupakan salah satu kemampuan matematis yang perlu dan penting dimiliki oleh mahasiswa pendidikan matematika. Pentingnya pemilikan kemampuan penalaran matematis pada mahasiswa pendidikan matematika sejalan dengan visi matematika khususnya untuk memenuhi kebutuhan masa yang akan datang. Sunendar (2016) mengemukakan bahwa pembelajaran matematika diarahkan untuk memberi peluang berkembangnya kemampuan bernalar, kesadaran terhadap kebermanfaatan matematika, menumbuhkan rasa percaya diri, sikap objektif dan terbuka untuk menghadapi masa depan yang selalu berubah. Penalaran menjadi penting dalam kehidupan apalagi dalam matematika. Karena dalam matematika memuat proses yang aktif, dinamis, dan generatif yang dikerjakan pelaku dan pengguna matematika (Schoenfeld, 2014). Pentingnya kemampuan penalaran matematis juga dikemukakan oleh Festiawan (2020) dan Suryaningrat et al. (2021) dimana penalaran matematis sangat penting dalam membantu individu tidak sekedar mengingat fakta, aturan dan langkah-langkah penyelesaian masalah, tetapi juga menggunakan keterampilan bernalarnya dalam melakukan pendugaan atas dasar pengalamannya sehingga yang bersangkutan akan memperoleh pemahaman konsep matematika yang saling berkaitan dan belajar secara bermakna (meaningful learning). Pernyataan tersebut menunjukkan bahwa penalaran dibutuhkan untuk membangun suatu gagasan matematika dan untuk menunjukkan bukti kebenaran dari gagasan tersebut.

Smith dan Kabele (2020) menjelaskan istilah penalaran/reasoning secara umum adalah proses berpikir yang berusaha menghubung-hubungkan fakta-fakta yang diketahui menuju kepada suatu kesimpulan. Sejalan juga dengan pendapat yang dikemukakan oleh Habibatul Izzah dan Azizah (2019) yang menyatakan penalaran merupakan kegiatan berpikir logis untuk mengumpulkan fakta, mengelola, menganalisis, menjelaskan dan membuat kesimpulan. Dalam matematika, penalaran matematis merupakan proses pencapaian kesimpulan logis berdasarkan fakta dan sumber yang relevan (Smith \& Kabele, 2020). Dilain pihak, fakta menunjukkan bahwa kemampuan penalaran matematis mahasiswa program studi pendidikan matematika FKIP UNRI belum terlalu baik atau masih rendah terutama pada matakuliah Masalah Nilai Awal dan Syarat Batas (MNASB). Hal ini ditunjukkan oleh fakta rendahnya capaian hasil belajar mahasiswa pada matakuliah tersebut dalam tiga tahun terakhir. Sejalan dengan hal tersebut, bebera penelitian terdahulu mendapati bahwa kemampuan mahasiswa pada mata kuliah MNASB masih tergolong rendah (Badu, 2013; Suanto et al., 2017; Wahyuni 2019). Mata kuliah ini juga tergolong sulit bagi mahasiswa karena memliki karakteristik yang kompleks untuk dipahami utamanya berkaitan pada sistem pemodelan dan komputasi (Badu, 2013). Oleh karena itu, mahasiswa perlu memiliki kemampuan penalaran yang baik pada mata kuliah MNASB.

Salah satu upaya yang dapat dilakukan untuk membantu meningkatkan kemampuan penalaran matematis mahasiswa adalah dengan mengembangkan bahan ajar (Pamungkas \& Yuhana, 2016). Bahan ajar yang dimaksud pada penelitian ini adalah modul. Modul merupakan suatu cara 
pengorganisasian materi perkuliahan yang memperhatikan tujuan pembelajaran (Nurmeidina et al., 2020). Berarti, perkuliahan dengan menggunakan modul diharapkan mampu membawa mahasiswa untuk mencapai tujuan perkuliahan yang diharapkan sesuai dengan kurikulum. Seterusnya, Nurmeidina et al. (2020) menyatakan bahwa strategi pengorganisasian materi perkuliahan menggunakan modul mengandung sequencing yang mengacu pada pembuatan urutan penyajian materi perkuliahan dan synthesizing yang mengacu pada penunjukkan kepada mahasiswa keterkaitan antara fakta, konsep, prinsip, dan prosedur yang terkandung dalam materi perkuliahan. Dalam merancang materi perkuliahan dengan menggunakan modul terdapat lima kategori kapabilitas yang diharapkan dapat dipelajari oleh mahasiswa, yaitu; (i) informasi verbal, (ii) keterampilan intelektual, (iii) strategi kognitif, (iv) sikap, dan (v) keterampilan motorik. Disamping itu, strategi pengorganisasian materi perkuliahan menggunakan modul terdiri dari tiga proses berpikir, yaitu; (i) pembentukan konsep, (ii) interpretasi konsep, dan (iii) aplikasi/prinsip (Nurmeidina et al., 2020).

Strategi-strategi tersebut memegang peranan yang sangat penting dalam mendesain pembelajaran perkuliahan. Manfaatnya diharapkan dapat membuat mahasiswa lebih tertarik dalam belajar, mahasiswa otomatis belajar bertolak dari prerequisites dan dapat meningkatkan kemampuan penalaran mahasiswa. Ini dibuktikan dengan hasil penelitian dari Erawanto dan Santoso (2016) dimana modul yang dihasilkan dapat meningkatkan kemampuan penalaran matematis siswa. Sejalan dengan hasil penelitian Pratiwi et al. (2021) bahwa penggunaan modul yang dikembangkan membantu meningkatkan kemampuan penalaran matematis siswa.

Berhubung dengan wabah Covid-19 yang mendunia termasuk di Indonesia tidak luput juga di Pekanbaru, Riau. Wabah ini telah memaksa institusi-institusi pendidikan tatap muka untuk bertransformasi menjadi pendidikan jarak jauh (distance education) secara daring (online). Dalam kondisi seperti ini E-modul merupakan satu alternatif atau kebutuhan yang dipandang penting dan diperlukan. E-Modul yang dimaksud dalam penelitian ini dimaknai sebagai suatu modul yang diberi tautan (link) secara online. Perkuliahan dengan menggunakan E-Modul ini memberi kemudahan kepada kedua belah pihak dosen dan mahasiswa dalam pelajaran secara daring (online). Sejalan dengan pendapat Sugiharni (2018) yang menyatakan e-modul dapat memudahkan proses pembelajaran secara mandiri karena berbantuan teknologi informasi, sehingga mudah diakses dimanapun dan kapanpun dibutuhkan.

Fakta menunjukkan bahwa program studi Pendidikan Matematika FKIP UNRI jurusan PMIPA belum tersedia e-modul yang mendukung pembelajaran secara online terutama pada mata kuliah MNASB. Hal ini peneliti ketahui karena peneliti sendiri adalah seorang dosen tetap di Program Studi Pendidikan Matematika FKIP UNRI dan mengampu matakuliah tersebut. Padahal e-modul memiliki peranan penting untuk memberi kemudahan kepada dosen dan mahasiswa dalam proses perkuliahan secara daring. Kemudahan diperoleh karena e-modul dikemas dengan memberikan materi pebelajaran, contoh soal yang non rutin, dan bahan evaluasi. Semua komponen e-mudul dengan mudah dapat 
Pengembangan E-Modul Matakuliah Masalah Nilai Awal Syarat Batas Berbasis Experiential Learning untuk Meningkatkan Kemampuan Penalaran Matematis Mahasiswa, Elfis Suanto, Armis, Syarifah Nur Siregar

diakses oleh setiap mahasiswa untuk bahan pembelajaran.

Peneliti pada penelitian ini akan mengembangkan e-modul matakuliah Masalah Nilai Awal Syarat Batas (MNASB) dengan pendekatan pembelajaran pengalaman (experiential learning) dari David Kolb. Experiential learning diartikan sebagai suatu pembelajaran yang melibatkan mahasiswa secara keseluruhan untuk membuat mereka mengalami masalah yang sedang digali, dan hasilnya akan berpengaruh kepada pemahaman kognitif dan afektif mahasiswa (Sholihah \& Mahmudi, 2015). Experiential learning suatu integrasi yang berada dalam suatu siklus yang dimulai dengan tahapan pemberian pengalaman konkrit, pengamatan yang bersifat reflektif, keterlibatan dalam konseptualisasi abstrak dan melakukan tindakan (Kolb, 1984). Keempat tahapan tersebut digambarkan oleh David Kolb dalam bentuk suatu kitaran seperti pada Gambar 1 (Sholihah \& Mahmudi, 2015).

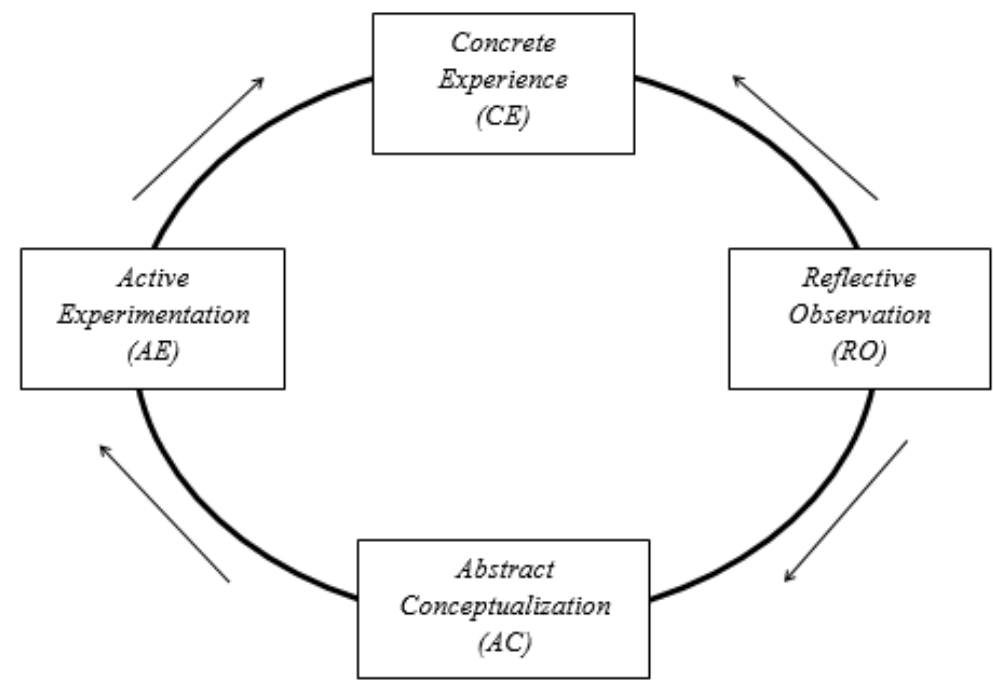

Gambar 1. Experiential Learning Circle

Pembelajaran experiential learning diyakini merupakan pendekatan pembelajaran yang sesuai dan cocok untuk pengajaran dan pembelajaran matematika (Borland, 2000). Penjabaran dari langkahlangkah experiential learning adalah sebagai berikut (Suanto et al., 2020):

Tabel 1. Langkah-langkah Experiential Learning

\begin{tabular}{|c|l|l|}
\hline No & \multicolumn{1}{|c|}{$\begin{array}{c}\text { Langkah-langkah } \\
\text { Experiential Learning }\end{array}$} & \multicolumn{1}{c|}{ Keterangan } \\
\hline 1 & Concrete experience & $\begin{array}{l}\text { Belajar dari pengalaman- pengalaman yang spesifik dan peka } \\
\text { terhadap situasi. }\end{array}$ \\
\hline 2 & Relative observation & $\begin{array}{l}\text { Mengamati sebelum membuat suatu keputusan dengan } \\
\text { mengamati lingkungan dari perspektif-perspektif yang } \\
\text { berbeda. }\end{array}$ \\
\hline 3 & Abstract conceptualization & $\begin{array}{l}\text { Analisis logis dari gagasan dan bertindak sesuai dengan } \\
\text { pemahaman pada suatu situasi. }\end{array}$ \\
\hline 4 & Active experimentation & $\begin{array}{l}\text { Kemampuan untuk melaksanakan berbagai hal dengan orang- } \\
\text { orang dan melakukan tindakan berdasarkan peristiwa, } \\
\text { termasuk pengambilan resiko. }\end{array}$ \\
\hline
\end{tabular}


Memahami masalah ini dan isu-isu yang ada serta kekuatan dari pendekatan experiential learning maka perlu ada upaya mengembangkan e-modul berbasis pendekatan experiential learning untuk membantu dosen dan mahasiswa. Permasalahan seterusnya adalah bagaimana mendesain (rekabentuk) dan mengembangkan e-modul berbasis pendekatan experiential learning yang valid dan praktis untuk digunakan dalam proses perkuliahan.

Tujuan utama penelitian ini adalah untuk mengembangkan E-Modul berbasis experiential learning matakuliah Masalah Nilai Awal dan Syarat Batas (MNASB) pada Program Studi Pendidikan Matematika Jurusan PMIPA FKIP UNRI yang valid dan praktis yang boleh digunakan sebagai salah satu sumber belajar pada matakuliah MNASB.

\section{METODE}

Penelitian ini dilaksanakan bermula bulan Februari hingga bulan Agustus 2021 (semester genap tahun ajaran 2020/2021). Desain yang diterapkan berupa development studies dengan dua tahapan yaitu tahapan preliminary evaluation dan formative evaluation (McKenney \& Reeves, 2012; MolasGallart et al., 2021). Adapun desain penelitian sebagai berikut.

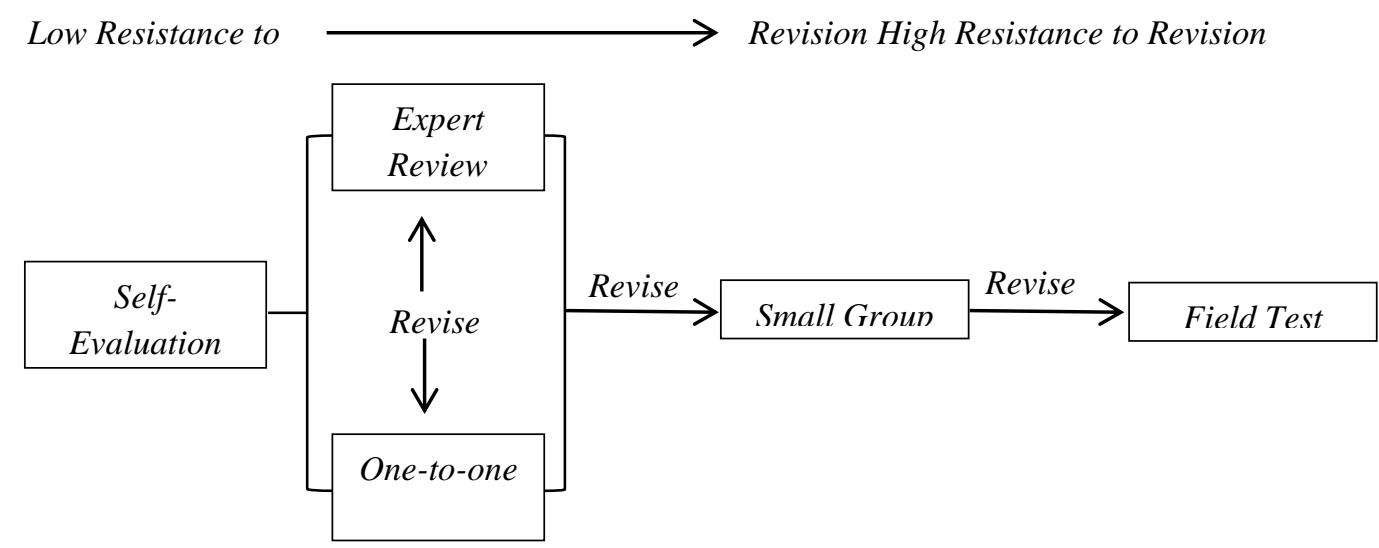

Gambar 2. Alur Desain Formative Evaluation

Penelitian pengembangan adalah suatu bentuk penelitian yang digunakan untuk menghasilkan produk tertentu dan menguji keefektifan produk tersebut (Creswell \& Creswell, 2018). E-Modul yang dikembangkan akan divalidasi oleh 3 orang pakar. E-Modul yang sudah memenuhi kriteria aspek validitas seterusnya akan dilakukan uji kepada sebanyak 32 mahasiswa program studi Pendidikan Matematika FKIP UNRI untuk mendapatkan data tentang aspek kepraktisannya. Analisis validasi EModul diperoleh dari data instrument validasi menggunakan rumus:

$$
\bar{M}_{v}=\frac{\sum_{i=1}^{n} \bar{V}_{i}}{n}
$$

$\bar{M}_{v}:$ Rata-rata total validitas

$\bar{V}_{i} \quad$ : Rata-rata validasi validator ke- $i$

$n$ : Banyaknya validator 
Pengembangan E-Modul Matakuliah Masalah Nilai Awal Syarat Batas Berbasis Experiential Learning untuk Meningkatkan Kemampuan Penalaran Matematis Mahasiswa, Elfis Suanto, Armis, Syarifah Nur Siregar

Tabel 2. Kategori Validitas E-Modul

\begin{tabular}{|c|c|}
\hline Interval & Kategori \\
\hline $3,25 \leq \bar{x}<4$ & Sangat Valid \\
\hline $2,50 \leq \bar{x}<3,25$ & Valid \\
\hline $1,75 \leq \bar{x}<2,50$ & Kurang Valid \\
\hline $1,00 \leq \bar{x}<1,75$ & Tidak Valid \\
\hline
\end{tabular}

Sumber: Sugiyono (2007)

Instrumen untuk melihat aspek validasi E-Modul tersebut menggunakan lembar validasi berupa pernyataan yang terdiri dari 45 pernyataan adaptasi dari Elmunsyah et al. (2018). Bentuk dari instrumen penilaian yang digunakan dalam penelitian ini yaitu angket tertutup dan terbuka. Angket tertutup digunakan untuk mendapatkan skor penilaian dan angket terbuka digunakan untuk mendapatkan komentar dan saran perbaikan dari pakar dan mahasiswa. Sedangkan, untuk melihat aspek kepraktisan E-Modul tersebut digunakan instrumen angket respon mahasiswa yang terdiri dari 12 pertanyaan tertutup dan 3 pertanyaan terbuka yang diisi oleh mahasiswa. Analisis kepraktisan EModul didapatkan dari hasil analisis data instrumen kepraktisan dengan menggunakan rumus modifikasi dari Elmunsyah et al. (2018) sebagai berikut:

$$
V_{p}=\frac{T_{s e}}{T_{s h}} \times 100 \%
$$

$V_{p} \quad$ : skor responden

$T_{s p}:$ total skor empiris dari responden

$T_{s h}:$ total skor maksimal yang diharapkan

Kriteria tingkat praktikalitasnya dapat dilihat pada Tabel 3.

Tabel 3. Tingkat kriteria praktikalitas

\begin{tabular}{|c|l|}
\hline \multicolumn{1}{|c|}{ Kriteria } & \multicolumn{1}{|c|}{ Tingkat Praktikalitas } \\
\hline $85,01 \% \leq x<100 \%$ & Sangat praktis \\
\hline $70,01 \% \leq x<85,00 \%$ & Praktis \\
\hline $50,01 \% \leq x<70,00 \%$ & Kurang praktis \\
\hline $01,00 \% \leq x<50,00 \%$ & Tidak praktis \\
\hline
\end{tabular}

Sumber: Modifikasi Elmunsyah et al. (2018)

Akhirnya, diharapkan diperoleh produk hasil penelitian berupa E-Modul berbasis pendekatan experiential learning pada matakuliah MNASB yang valid dan praktis serta berpotensi dapat mengoptimalkan kemampuan penalaran matematis mahasiswa.

\section{HASIL DAN DISKUSI}

\section{Preliminary Evaluation}

Pada tahap-tahap pengembangan yang telah dilaksanakan, dihasilkan suatu produk berupa EModul topik Masalah Nilai Awal dan Syarat Batas berdasarkan pendekatan pembelajaran pengalaman (experiential learning) untuk meningkatkan kemampuan penalaran matematis mahasiswa. Pada tahap 
analysis, bertolak dari fakta yang menyebutkan bahwa kemampuan penalaran matematis mahasiswa program studi Pendidikan Matematika FKIP UNRI belum terlalu baik kalau tidak akan dikatakan rendah terutama pada matakuliah Masalah Nilai Awal dan Syarat Batas (Suanto et al., 2017; Wahyuni, 2019). Hal ini ditunjukkan oleh fakta rendahnya capaian hasil belajar mahasiswa pada matakuliah tersebut dalam tiga tahun terkahir. Aktiviti utama dilakukan analisis keperluan pembangunan bahan baru dan menganalisis kebolehan dan syarat-syarat pembangunan bahan tersebut. Hasil dari tahap analisis diperoleh beberapa aspek pembangunan bahan baru meliputi kualitas materi E-Modul, kesesuaian dengan pendekatan experiential learning, kesesuaian dengan syarat didaktik, kesesuaian dengan ketatabahasaan yang baik dan konstruk, kesesuaian dengan syarat teknis, serta memperhatikan penampilan E-Modul.

Dalam perancangan E-Modul, peringkat desain memiliki kesamaan dengan merancang bahan ajar. Kegiatan ini merupakan proses sistematik yang dimulai daripada menetapkan sasaran pembelajaran, merancang materi pembelajaran dan alat penilaian pencapaian belajar. Rancangan EModul ini masih bersifat konseptual dan akan mendasari proses pembangunan berikutnya.

\section{Formative Evaluation}

Tahapan ini terdiri dari 5 fase besar, yaitu self-evaluation, expert review, one-to-one, small group, dan field test (Suanto et al., 2017). Pada setiap fase memiliki maksud dan tujuan tertentu, fase pertama sampai keempat merupakan proses validasi dari E-Modul yang dikembangkan sehingga akan muncul beberapa prototipe E-Modul. Prototipe final yang diperoleh nantinya akan diujikan pada fase field test untuk melihat efek potensial dari E-Modul terhadap kemampuan penalaran matematis mahasiswa.

\section{Self-Evaluation}

Hasil Evaluasi pada tahapan ini tidak banyak mengalami perubahan yang signifikan, selain pada pemeriksaan kesalahan penulisan dan pendesainan ulang tema dari E-Modul untuk disesuaikan dengan materi.

\section{Expert Review}

Uji kevalidan E-Modul pada prototype I dievaluasi oleh 3 orang dosen pakar, yang terdiri dari pakar materi, pakar pembelajaran, dan pakar media. Berikut rata-rata hasil perhitungan kriteria angket validasi dari expert review.

Tabel 4. Hasil validasi E-Modul oleh pakar

\begin{tabular}{|c|l|c|l|}
\hline No & Aspek yang dinilai & Rata-rata & \multicolumn{1}{|c|}{ Kriteria } \\
\hline 1 & Relevansi materi ke sasaran kompetensi perkuliahan & 3,71 & Sangat Valid \\
\hline 2 & Keakuratan materi berdasarkan konsep keilmuan & 3,75 & Sangat Valid \\
\hline 3 & Memuat kegiatan pendekatan experiential learning & 3,92 & Sangat Valid \\
\hline 4 & Penyajian materi sesuai tahapan berpikir & 3,83 & Sangat Valid \\
\hline 5 & Kesesuaian dengan kemampuan mahasiswa & 4,00 & Sangat Valid \\
\hline 6 & Kegiatan yang melibatkan kemampuan penalaran matematis & 3,40 & Sangat Valid \\
\hline
\end{tabular}


Pengembangan E-Modul Matakuliah Masalah Nilai Awal Syarat Batas Berbasis Experiential Learning untuk Meningkatkan Kemampuan Penalaran Matematis Mahasiswa, Elfis Suanto, Armis, Syarifah Nur Siregar

\begin{tabular}{|c|l|c|l|}
\hline 7 & Ketepatan penggunaan bahasa dan kalimat & 3,75 & Sangat Valid \\
\hline 8 & Ukuran e-Modul & 4,00 & Sangat Valid \\
\hline 9 & Desain kulit E-Modul & 3,87 & Sangat Valid \\
\hline 10 & Desain isi E-Modul & 3,76 & Sangat Valid \\
\hline \multicolumn{2}{r|}{ JUMLAH } & $\mathbf{3 7 , 9 9}$ & \\
\hline \multicolumn{2}{r|}{ RATA-RATA } & $\mathbf{3 , 8 0}$ & Sangat Valid \\
\hline
\end{tabular}

Aspek relevansi materi ke sasaran kompetensi perkuliahan pada E-Modul yang dikembangkan diperoleh nilai rata-rata validasi sebesar 3,71 yang dikategorikan sangat valid. Maksud dari nilai 3,71 tersebut adalah materi yang disajikan pada E-Modul yang dikembangkan sesuai dengan tujuan perkuliahan yang diharapkan. Pada aspek keakuratan materi berdasarkan konsep keilmuan mendapat nilai rata-rata validasi sebesar 3,75 yang dikategorikan sangat valid. Maksud dari nilai tersebut adalah materi yang disajikan pada E-Modul yang dikembangkan sudah benar dan tepat, ilustrasi yang diberikan sesuai dengan materi, penggunaan notasi; istilah; dan simbol yang sesuai serta contoh soal dan soal latihan sesuai dengan materi yang dipelajari. E-Modul memuat kegiatan pendekatan experiential learning diperoleh nilai rata-rata validasi sebesar 3,92 dengan kategori sangat valid. Artinya E-Modul yang dikembangkan berasaskan pendekatan experiential learning melalui pemberian masalah kontekstual pada kegiatan mahasiswa untuk memberikan pengalaman konkrit, memberi ruang kepada mahasiswa untuk menyelidiki atau pengamatan yang bersifat reflektif, memberi ruang kepada mahasiswa untuk menyimpulkan konsep, serta memberikan soal latihan sebagai wujud dari mengeksperimenkan konsep yang telah ditemukan (Sholihah \& Mahmudi, 2015; Sugiharni, 2018).

Selanjutnya penilaian mengenai penyajian materi sesuai dengan tahapan berpikir yang memperoleh nilai rata-rata validasi sebesar 3,83 dengan kategori sangat valid. Maksudnya adalah materi yang disajikan pada E-Modul yang dikembangkan menyajikan masalah yang kontekstual dimana akan menuntut mahasiswa untuk merumuskan masalah tersebut. Setelah masalah dirumuskan akan disusun kerangka berpikir, selanjutnya akan dibentuk hipotesis dan dilakukan eksperimen, diakhiri dengan penarikan kesimpulan. Aspek penilaian kesesuaian dengan kemampuan mahasiswa memperoleh nilai rata-rata validasi 4,00 yang dikategorikan sangat valid, artinya E-Modul dapat digunakan oleh mahasiswa dengan kemampuan rendah, sedang, maupun tinggi. Selain itu kegiatan yang tersaji dalam E-Modul juga melibatkan kemampuan penalaran matematis mahasiswa dimana nilai rata-rata validasinya sebesar 3,40 dengan kategori sangat valid. Dikatakan sangat valid karena penyajian materi dan kegiatan pada E-Modul didukung dengan pemberian informasi yang sesuai serta berpotensi melatih kemampuan penalaran matematis mahasiswa.

Aspek penilaian selanjutnya adalah ketepatan penggunaan bahasa dan kalimat yang mendapatkan nilai rata-rata validasi 3,75 dengan kategori sangat valid. Dikategorikan sangat valid karena penggunaan bahasa pada E-Modul yang dikembangkan sesuai dengan tingkat pemahaman 
mahasiswa dengan menggunakan bahasa yang komunikatif dan tidak menimbulkan makna ganda serta menggunakan struktur kalimat yang jelas. Aspek penilaian ukuran E-Modul dengan nilai ratarata 4,00, desain kulit E-Modul 3,87, dan desain isi E-Modul dengan nilai 3,76 yang setiap poin dikategorikan sangat valid. Dikategorikan sangat valid karena penyajian E-Modul didesain semenarik mungkin agar dapat menarik perhatian mahasiswa dan tidak menimbulkan efek jenuh dalam proses pembelajaran. Secara keseluruhan tidak terdapat perubahan yang siginfikan setelah expert review, perubahan meliputi tata letak modul, kerapian, dan kekonsistenan penulisan. Sejalan dengan dilakukannya expert review dilakukan juga one-to-one evaluasi yang dilaksanakan oleh Sembilan mahasiswa yang mengikuti matakuliah MNASB kelas A.

\section{One-to-One}

Pada tahap ini, prototipe I diberikan kepada sembilan orang mahasiswa matakuliah MNASB kelas A Pendidikan Matematika FKIP Universitas Riau dengan tingkat kemampuan kognitif yang berbeda-beda, kegiatan ini dilaksanakan dengan tujuan untuk melihat keterbacaan E-Modul dan melihat respon mahasiswa terhadap E-Modul yang dikembangkan.

Pada saat evaluasi satu-satu mahasiswa diberikan beberapa pertanyaan terkait E-Modul yang dikembangkan, selanjutnya mahasiswa memberikan tanggapan pada aspek pertanyaan bagaimana pandangan mahasiswa terhadap E-Modul yang dikembangkan ini dari aspek format E-Modul (kulit luar, bentuk tulisan, gambar rajah, dll).

Tabel 5. Komentar dan saran mahasiswa terhadap aspek format E-Modul

\begin{tabular}{|l|l|}
\hline No & \multicolumn{1}{|c|}{ Komentar dan Saran } \\
\hline 1 & Kurang dilengkapi ilustrasi gambar, \\
\hline 2 & $\begin{array}{l}\text { Secara umum E-Modul yang dikembangkan sudah bagus, namun pada halaman isi mungkin } \\
\text { akan lebih menarik jika gambar diberikan warna yang bebeda untuk bagian-bagian pentingnya, }\end{array}$ \\
\hline 3 & Kulit luar terkesan baik, tulisan jelas dan lumayan besar sehingga mudah dibaca, \\
\hline 4 & $\begin{array}{l}\text { Berdasarkan aspek kulit luar terlihat bagus dan tulisan juga unik namun untuk tulisan warna } \\
\text { kuning pada kulit luar sebaiknya lebih dibesarkan lagi atau lebih dijarakkan karena masih ada } \\
\text { ruang di sampingnya, }\end{array}$ \\
\hline 5 & $\begin{array}{l}\text { Bagus, tulisan yang sangat jelas dan warna yang tidak terlalu banyak sehingga terlihat elegan } \\
\text { namun bagus, }\end{array}$ \\
\hline 6 & $\begin{array}{l}\text { Kulit luar sangat menarik, bentuk tulisan juga mudah dibaca, namun bagian dalam E-Modul } \\
\text { seperti buku biasa, hanya pada judul-judul besar yang ada warna, jika pada foother atau tempat } \\
\text { halaman ditambah line yang berwarna mungkin lebih menarik, sehingga agak mengurangi } \\
\text { kejenuhan mahasiswa membaca karna menarik, }\end{array}$ \\
\hline 7 & $\begin{array}{l}\text { Menurut saya, bentuk tulisannya kurang menarik, masih menggunakan tulisan biasa, warna nya } \\
\text { juga kurang menarik, karena di tengah-tengahnya masih putih polos, kalau ada tambahan warna } \\
\text { mungkin akan lebih bagus dan menarik minat mahasiswa untuk membaca. Kulit luarnya sudah } \\
\text { lumayan bagus, karena sudah ada warna disana sehingga enak dilihat, }\end{array}$ \\
\hline 8 & Kulit luar sudah menggambarkan modul mata kuliah bidang matematika, \\
\hline 9 & $\begin{array}{l}\text { Pandangan saya dari segi kulit luar, bentuk tulisan, gambar bagus. Akan tetapi masih ada } \\
\text { kesalahan penulisan di teladan 16. }\end{array}$ \\
\hline
\end{tabular}

Berdasarkan saran dan komentar yang diberikan oleh mahasiswa terhadap aspek format EModul pada Tabel 5 dapat disimpulkan beberapa perubahan yang akan dilakukan. Bagian kulit luar 
Pengembangan E-Modul Matakuliah Masalah Nilai Awal Syarat Batas Berbasis Experiential Learning untuk Meningkatkan Kemampuan Penalaran Matematis Mahasiswa, Elfis Suanto, Armis, Syarifah Nur Siregar

membutuhkan beberapa perbaikan untuk memaksimalkan ruang agar lebih proporsional. Pada bagian isi dari E-Modul akan ditambahkan beberapa gambar yang lebih menarik dengan warna yang sesuai. Untuk ukuran dan jenis tulisan akan diperbaiki dengan jenis dan ukuran yang lebih menarik. Selanjutnya untuk pertanyaan bagaimanakah pandangan mahasiswa terhadap E-Modul yang peneliti kembangkan ini secara keseluruhan. Jawaban yang diberikan mahasiswa adalah seperti dilihat pada Tabel 6.

Tabel 6. Komentar dan saran mahasiswa terhadap E-Modul secara keseluruhan

\begin{tabular}{|l|l|}
\hline No & \multicolumn{1}{|c|}{ Komentar dan Saran } \\
\hline 1 & $\begin{array}{l}\text { E-Modul yang dikembangkan ini sangat membantu mahasiswa dalam memahami materi } \\
\text { karena disajikan secara ringkas dan to the point, }\end{array}$ \\
\hline 2 & $\begin{array}{l}\text { Secara keseluruhan E-Modul sudah bagus, tetapi mungkin bisa lebih di berikan desain yang } \\
\text { menarik, }\end{array}$ \\
\hline 3 & Bagus, \\
\hline 4 & $\begin{array}{l}\text { Menurut saya, secara keseluruhan E-Modul ini sudah bagus, dari segi materi sudah dijelaskan } \\
\text { dengan singkat, padat, dan jelas, hanya saja perlu adanya kreatifitas dalam segi tampilan saja, }\end{array}$ \\
\hline 5 & Sudah praktis dan cukup efisien, \\
\hline 6 & $\begin{array}{l}\text { Menurut saya, sangat memudahkan dan membantu dalam mempelajari materi MNASB ini } \\
\text { dengan menggunakan E-Modul. }\end{array}$ \\
\hline
\end{tabular}

Berdasarkan Tabel 6 terlihat bahwa secara keseluruhan E-Modul yang dikembangkan sudah membantu mahasiswa dalam mempelajari matakuliah MNASB. Hanya saja pada bagian desain masih perlu perbaikan agar lebih menarik. Hasil keseluruhan perbaikan terhadap prototype I dinamakan prototype II. Dalam hal ini prototype II dapat dikatakan sudah valid secara kualitatif, berdasarkan hasil perbaikan, masukan, dan saran pada tahapan expert review dan one-to-one serta valid secara kuantitatif berdasarkan angket validasi dengan 10 (sepuluh) aspek yang dinilai dengan kriteria sangat valid (lihat kriteria Tabel 2). Selanjutnya prototype II diujicobakan pada tahapan small group.

\section{Small Group}

Pada tahap ini, prototype II diujicobakan kepada dua puluh orang mahasiswa matakuliah MNASB dari kelas A Pendidikan Matematika yang bukan merupakan subjek dari penelitian utama untuk pengujian E-Modul pada fase field test. Tahap ini dilaksanakan dengan tujuan agar peneliti dapat mengamati kendala dan respon mahasiswa ketika menggunakan E-Modul sebelum digunakan pada tahap field test.

Tahapan selanjutnya, mahasiswa diberikan angket respon mahasiswa dengan tujuan untuk melihat sejauh mana respon mahasiswa terhadap kepraktisan penggunaan E-Modul pada kelompok kecil. Hasil yang diperoleh disajikan pada Tabel 7. Skor angket respon mahasiswa pada tahap small test.

Tabel 7. Hasil angket respon mahasiswa pada tahap small test

\begin{tabular}{|c|l|c|c|}
\hline No. & Butir Penilaian & Skor & Kriteria \\
\hline 1. & E-Modul dapat diakses dimana saja dan kapan saja. & 93,75 & Sangat Praktis \\
\hline 2. & Penggunaan E-Modul menghemat waktu pembelajaran saya. & 75 & Praktis \\
\hline
\end{tabular}




\begin{tabular}{|c|l|c|c|}
\hline 3. & Materi dalam E-Modul mudah untuk saya pahami. & 80 & Praktis \\
\hline 4. & Latihan soal yang ada dalam E-Modul jelas dan dapat saya pahami. & 80 & Praktis \\
\hline 5. & Bahasa yang digunakan dalam E-Modul mudah untuk saya pahami. & 78,75 & Praktis \\
\hline 6. & $\begin{array}{l}\text { Saya dapat belajar secara mandiri menggunakan E-Modul yang } \\
\text { diberikan. }\end{array}$ & 77,5 & Praktis \\
\hline 7. & $\begin{array}{l}\text { Cara penggunaan E-Modul diberikan dengan jelas dan dapat saya } \\
\text { pahami. }\end{array}$ & 83,75 & Praktis \\
\hline 8. & $\begin{array}{l}\text { Dengan E-Modul saya dapat mempelajari materi yang saya inginkan } \\
\text { secara berulang. }\end{array}$ & 87,5 & Sangat Praktis \\
\hline 9. & Desain tampilan E-Modul menarik. & 75 & Praktis \\
\hline 10. & $\begin{array}{l}\text { Isi E-Modul dilengkapi dengan ilustrasi maupun gambar yang sesuai } \\
\text { dengan materi. }\end{array}$ & 76,25 & Praktis \\
\hline 11. & Pemilihan jenis dan ukuran font menarik dan dapat dibaca. & 90 & Sangat Praktis \\
\hline 12. & Kombinasi warna dalam E-Modul menarik. & 72,5 & Praktis \\
\hline \multicolumn{2}{|r|}{ JUMLAHA } & $\mathbf{9 7 0}$ & Praktis \\
\hline
\end{tabular}

Berdasarkan Tabel 7 butir penilaian mengenai kemudahan akses E-Modul; jenis dan ukuran font; penggunaan E-Modul yang bisa diakses berulang memenuhi kriteria sangat praktis, artinya pada bagian tersebut tidak perlu dilakukan perbaikan. Butir penilaian mengenai waktu pembelajaran; desain tampilan E-Modul; isi E-Modul yang terdapat ilustrasi dan gambar; kombinasi warna sudah dalam kriteria praktis, tetapi skor persentase menunjukkan masih rendah dari yang lainnya. Hal ini mengindikasikan butir penilaian tersebut masih diperlukan perbaikan dibeberapa aspek. Butir penilaian lainnya juga sudah memenuhi kriteria praktis. Secara keseluruhan Tabel 7 menunjukkan bahwa skor rata-rata yaitu 80,83 yang artinya tingkat kepraktisan penggunaan E-Modul masuk kriteria praktis. Selain melihat kriteria kepraktisan, peneliti juga menganalisis saran dan masukan mahasiswa sebagai perbaikan dari prototype II sebelum diujicobakan pada tahap field test. Sejumlah saran dan masukan dari mahasiswa dideskripsikan pada Tabel 8.

Tabel 8. Komentar dan saran mahasiswa terhadap E-Modul pada tahap small test

\begin{tabular}{|l|l|}
\hline No & \multicolumn{1}{|c|}{ Komentar dan Saran } \\
\hline 1 & $\begin{array}{l}\text { Secara keseluruhan E-modul yang dikembangkan sudah bagus dan mudah dipahami. Tetapi akan } \\
\text { lebih bagus lagi apabila contoh soal pada modul diperbanyak, }\end{array}$ \\
\hline 2 & Sudah sesuai untuk kebutuhan para pembaca, \\
\hline 3 & E-Modul adalah salah satu trobosan yg sangat sesuai dengan sistem pembelajaran saat ini, \\
\hline 4 & $\begin{array}{l}\text { Secara keseluruhan E-Modul sudah bagus, tetapi mungkin bisa lebih di berikan desain yang } \\
\text { menarik, }\end{array}$ \\
\hline 5 & Sangat membantu, mudah dipahami, mungkin contoh yang diberikan bisa lebih banyak, \\
\hline 6 & $\begin{array}{l}\text { Menurut saya, sudah baik dan bagus hanya saja dalam pengemasan E-Modul yang belum } \\
\text { menarik sebagai contoh pada bagian kulit luar, }\end{array}$ \\
\hline 7 & $\begin{array}{l}\text { Menurut saya, E-Modul ini sangat bagus dan sangat berguna untuk mahasiswa. Hanya saja E- } \\
\text { Modul lebih baik dibuat semenarik mungkin agar mahasiswa nyaman membaca E-Modul dan } \\
\text { mempermudah memahami pembelajaran, }\end{array}$ \\
\hline 8 & $\begin{array}{l}\text { Menurut saya, secara keseluruhan E-Modul ini sudah bagus, dari segi materi sudah dijelaskan } \\
\text { dengan singkat, padat, dan jelas, hanya saja perlu adanya kreatifitas dalam segi tampilan saja, }\end{array}$ \\
\hline 9 & E-Modul secara materi sudah lengkap, hanya saja mungkin penambahan contoh soal yang bisa \\
\hline
\end{tabular}




\begin{tabular}{|c|l|}
\hline & mewakili bentuk-bentuk latihan soal yang ada, \\
\hline 10 & $\begin{array}{l}\text { E-Modul yang dikembangkan dapat membantu dalam pembelajaran jarak jauh dan tampilannya } \\
\text { juga bagus. Materi dijabarkan secara runtut, }\end{array}$ \\
\hline 11 & $\begin{array}{l}\text { Menurut saya, sangat memudahkan dan membantu dalam mempelajari materi MNASB ini } \\
\text { dengan menggunakan E-Modul, }\end{array}$ \\
\hline 12 & $\begin{array}{l}\text { Dalam segi penulisan sudah baik dan dapat dengan jelas dibaca. Tapi lebih baik jika diberikan } \\
\text { banyak ilustrasi dan sedikit warna agar lebih menarik dibaca, }\end{array}$ \\
\hline
\end{tabular}

Berdasarkan masukan dan saran mahasiswa pada small group, sejumlah perbaikan yang signifikan terhadap prototype II, diantaranya yaitu petunjuk penggunaan E-Modul dibuat dengan tujuan agar mahasiswa mudah memahami dan menggunakannya. Setelah fase small group, petunjuk penggunaan diperjelas dengan menambahkan petunjuk perkuliahan berdasarkan tahap pendekatan experiential learning sehingga lebih memudahkan mahasiswa dalam menggunakan E-Modul. Selain itu, pada bagian awal bab ada beberapa masalah kontekstual yang dianggap kurang dimengerti oleh mahasiswa. Hasil perbaikan pada prototype II, setelah melalui tahapan small group, selanjutnya disebut sebagai prototype III. Dalam hal ini prototype III sudah dapat dikatakan valid dan praktis secara kualitatif, berdasarkan masukan dan saran, serta kemudahan penggunaan E-Modul.

Secara kuantitatif kepraktisan berdasarkan perhitungan angket yaitu dengan kriteria praktis (lihat Tabel 7). Untuk selanjutnya, prototype III diuji coba pada tahapan field test untuk melihat efek potensial E-Modul ini pada kemampuan penalaran matematis mahasiswa. Pada tahapan ini, prototipe III diujicobakan kepada mahasiswa matakuliah MNASB kelas B Pendidikan Matematika Universitas Riau yang merupakan subjek penelitian yang terdiri dari 32 orang mahasiswa.

Pada akhir tahap ini, peneliti memberikan angket respon mahasiswa dengan tujuan untuk melihat tingkat kepraktisan penggunaan E-Modul serta saran dan masukan setelah perkuliahan selesai dilaksanakan. Hasil dari angket tersebut disajikan pada Tabel 9.

Tabel 9. Hasil angket respon mahasiswa pada tahap field test

\begin{tabular}{|c|l|c|c|}
\hline No. & Butir Penilaian & Skor & Kriteria \\
\hline 1. & E-Modul dapat diakses dimana saja dan kapan saja. & 90,6 & Sangat Praktis \\
\hline 2. & Penggunaan E-Modul menghemat waktu pembelajaran saya. & 82,8 & Praktis \\
\hline 3. & Materi dalam E-Modul mudah untuk saya pahami. & 84,4 & Praktis \\
\hline 4. & $\begin{array}{l}\text { Latihan soal yang ada dalam E-Modul jelas dan dapat saya } \\
\text { pahami. }\end{array}$ & 81,3 & Praktis \\
\hline 5. & $\begin{array}{l}\text { Bahasa yang digunakan dalam E-Modul mudah untuk saya } \\
\text { pahami. }\end{array}$ & 82,8 & Praktis \\
\hline 6. & $\begin{array}{l}\text { Saya dapat belajar secara mandiri menggunakan E-Modul yang } \\
\text { diberikan. }\end{array}$ & 79,7 & Praktis \\
\hline 7. & $\begin{array}{l}\text { Cara penggunaan E-Modul diberikan dengan jelas dan dapat saya } \\
\text { pahami. }\end{array}$ & 82,8 & Praktis \\
\hline 8. & $\begin{array}{l}\text { Dengan E-Modul saya dapat mempelajari materi yang saya } \\
\text { inginkan secara berulang. }\end{array}$ & 88,3 & Sangat Praktis \\
\hline 9. & Desain tampilan E-Modul menarik. & 81,3 & Praktis \\
\hline 10. & Isi E-Modul dilengkapi dengan ilustrasi maupun gambar yang & 81,3 & Praktis \\
\hline
\end{tabular}




\begin{tabular}{|r|l|c|c|}
\hline & sesuai dengan materi. & & \\
\hline 11. & Pemilihan jenis dan ukuran font menarik dan dapat dibaca. & 87,5 & Sangat Praktis \\
\hline 12. & Kombinasi warna dalam E-Modul menarik. & 82,0 & Praktis \\
\hline \multicolumn{2}{r}{ JUMLAH } & $\mathbf{1 0 0 4 , 7}$ & \\
\hline \multicolumn{2}{r|}{ RATA-RATA } & $\mathbf{8 3 , 7}$ & Praktis \\
\hline
\end{tabular}

Berdasarkan Tabel 9 terlihat bahwa kemudahan akses; dapat diakses secara berulang; jenis dan ukuran font sudah sangat praktis. Butir penilaian yang sudah diperbaiki dan ditambahkan pada tahap sebelumnya sudah memperoleh persentase yang tidak jauh berbeda dengan butir penilaian lainnya dengan kriteria praktis. Secara keseluruhan pada Tabel 9, terlihat bahwa hasil kriteria kepraktisan penggunaan E-Modul pada kelas field test berada pada kriteria praktis. Selanjutnya, pasca perkuliahan menggunakan E-Modul menggunakan pendekatan experiential learning pada matakuliah Masalah Nilai Awal dan Syarat Batas, sejumlah saran dan masukan melalui respon mahasiswa dapat dilihat pada Tabel 10.

Tabel 10. Komentar dan saran mahasiswa pada tahap field test

\begin{tabular}{|c|l|}
\hline No & \multicolumn{1}{|c|}{ Komentar dan Saran } \\
\hline 1 & Sudah cukup baik dan lebih baik dibanding sebelumnya, \\
\hline 2 & E-Modul dapat mewakili pembelajaran, memudahkan pelajar dalam belajar, \\
\hline 3 & Secara keseluruhan E-Modul sudah sangat baik, \\
\hline 4 & Sangat membantu dalam pembelajaran, \\
\hline 5 & Sangat baik dan mudah dipahami, \\
\hline 6 & E-Modul yang disajikan menarik dan mudah dipahami, \\
\hline 7 & $\begin{array}{l}\text { Menurut saya sudah sangat bagus karena penyampaian materi terstruktur, bahasa yang digunakan } \\
\text { sederhana sehingga mudah dimengerti, sudah memuat contoh soal dan latihan, mungkin hanya } \\
\text { perlu ditambahkan beberapa persoalan yang konseptual untuk beberapa materi tertentu, }\end{array}$ \\
\hline 8 & Secara keseluruhan, E-Modul ini sangat membantu dari segi kepraktisan, \\
\hline 9 & $\begin{array}{l}\text { Modul sangat membantu mahasiswa dalam memahami materi mengenai MNA\&SB. Modul } \\
\text { sangat fleksibel sehingga bisa diakses dan dibuka dimana saja, }\end{array}$ \\
\hline 10 & $\begin{array}{l}\text { Sangat menarik, karena mampu mengubah suasana kelas lebih menyenangkan mampu membantu } \\
\text { mahasiswa berpikir kritis dan mahasiswa jadi tidak bingung untuk mencari konsep jika lupa bisa } \\
\text { membuka E-Modul, tetapi masih sangat sulit jika memelahaminya sendiri tanpa bimbingan, }\end{array}$ \\
\hline 11 & Menurut saya E-Modul secara keseluruhan sangat bagus dan bagus untuk digunakan, \\
\hline 12 & $\begin{array}{l}\text { Secara keseluruhan, menurut saya E-Modul ini sudah sangat bagus untuk dikembangkan dan di } \\
\text { cobakan kepada pengguna secara luas, }\end{array}$ \\
\hline 13 & Secara keseluruhan E-Modul yang dibuat sudah bagus dan menarik untuk dipelajari, \\
\hline 14 & Menurut saya secara keseluruhan modul ini sudah sangat bagus, \\
\hline 15 & $\begin{array}{l}\text { E-Modul sudah baik karna sudah sesuai standar dan mudah untuk difahami dan dipelajari secara } \\
\text { mandiri, }\end{array}$ \\
\hline 16 & $\begin{array}{l}\text { E-Modul yang dikembangkan sudah sangat baik, praktis, dan efisien digunakan dalam proses } \\
\text { pembelajaran, }\end{array}$ \\
\hline
\end{tabular}

Selanjutnya, hasil penelitian yang telah dideskripsikan berdasarkan tahapan-tahapan penelitian design research dengan tipe development studies, dibahas secara komprehensif. Pada tahap 
preliminary evaluation, peneliti melakukan penyelidikan terhadap analisis kurikulum, materi dan karakteristik mahasiswa yang akan dibutuhkan dalam proses perkuliahan (Suanto et al., 2017). Bertolak dari fakta yang menyatakan kemampuan penalaran matematis mahasiswa program studi Pendidikan Matematika FKIP UNRI belum terlalu baik kalau tidak akan dikatakan rendah terutama pada matakuliah Masalah Nilai Awal dan Syarat Batas (MNASB). Hal ini ditunjukkan oleh rendahnya capaian hasil belajar mahasiswa pada matakuliah tersebut dalam tiga tahun terakhir. Aktivitas utama yang dilakukan adalah analisis keperluan pembangunan bahan baru dan menganalisis kebolehan serta syarat-syarat pembangunan bahan tersebut. Hasil ini akan digunakan sebagai dasar untuk melanjutkan penelitian ke tahapan desain perangkat pembelajaran yang disebut dengan prototipe I.

Pada tahap formative evaluation, prototype I dikumpulkan untuk selanjutnya dievaluasi pada tahapan self-evaluation. Hasil pada tahapan ini meliputi E-Modul menggunakan pendekatan experiential learning pada matakuliah MNASB, lembar penilaian kualitas produk oleh ahli, serta angket respon mahasiswa. Selanjutnya E-Modul pada prototype I memasuki tahap expert review dan one-to-one. Berdasarkan hasil evaluasi dari expert review dan one-to-one, E-Modul dikatakan valid dari segi materi maupun media yang digunakan dengan kriteria sangat valid yang selanjutnya disebut sebagai prototype II.

Setelah E-Modul pada prototype II dinyatakan valid, selanjutnya menguji kepraktisan prototype II melalui observasi pada tahap small group. Aspek kriteria kepraktisan dinilai dari angket respon mahasiswa baik dari segi penyajian materi, kegrafikan, dan manfaat. Pada tahap ini 20 orang mahasiswa matakuliah MNASB kelas A dengan kemampuan kognitif yang tinggi, sedang, dan rendah. Dalam hal ini, mahasiswa dapat menggunakan E-Modul dengan baik. Masalah kontekstual yang diberikan pada E-Modul juga dapat dikenali mahasiswa, mudah dibaca, serta mahasiswa dapat dengan mudah menyelesaikan latihan dan himpunan soal yang diberikan pada E-Modul. Hasil masukan dan saran pada tahap small group digunakan untuk merevisi prototype II. Hasil perbaikan dari prototype II selanjutnya disebut dengan prototype III yang valid dan praktis dengan kriteria praktis. Protoipe III yang valid dan praktis kemudian diujicobakan pada tahap field test. Berdarkan hasil field test, tidak ada kendala berarti yang dialami oleh mahasiswa dalam mengimplementasikan E-Modul.

Pada E-Modul, materi perkuliahan disesuaikan dengan menggunakan karakteristik pendekatan experiential learning dari Kolb (1984) yaitu Concrete Experience, Reflective Observation, Abstract Conceptualisation, Active Experimentation. Implementasi dalam penerapan modul berbasis experiential learning menurut Lubis et al. (2020) sangat membantu mahasiswa calon guru untuk mengembangkan profesionalismenya. Tuntutan lebih akan inovasi dalam pembelajaran memungkinkan mahasiswa untuk berpikir kritis dan kreatif dalam pembelajaran serta proses berbagi pengalaman. Proses pengamatan memberikan peluang untuk mengembangkan keterbukaan dan kompetensi sosialnya. Serta proses refleksi secara berkelanjutan menjadi ajang untuk menumbuhkan 
kesadaran akan keterbatasannya.

Pedoman konkrit (concrete experience) yaitu mahasiswa terlibat secara langsung dalam suatu kegiatan/aktiviti pembelajaran sehingga memberikan pengalaman konkrit yang menjadi dasar kepada perasaan (feeling) mahasiswa untuk membangun atau mendapatkan ilmu baru. Pengamatan reflektif (reflective observation) yaitu berdasarkan pengalaman konkrit dengan menggunakan fungsi penglihatan (watching) maka mahasiswa melakukan pengamatan yang bersifat reflektif sehingga diperoleh data atau informasi-informasi untuk membangun ilmunya. Kemudian berdasarkan data atau informasi itu, selanjutnya mahasiswa melakukan proses pengkonseptualan yang bersifat abstrak (abstract conceptualization) dengan melibatkan fungsi pikiran (thinking) sedangkan eksperimentasi aktif (active experimentation) merupakan tindakan atau perbuatan (doing) berupa percobaan menggunakan pengkonseptualan tersebut (Kolb, 1984).

Sejalan dengan temuan dari Sholihah dan Mahmudi (2015) dimana concrete experiment merupakan proses berpikir secara terbuka dan beradaptasi, serta adanya sensitivitas terhadap diri sendiri dan perasaan orang lain. Reflective Observation adalah tahapan dimana siswa melihat, mendengar, dan memandang permasalahan dari sudur pandang yang berbeda, serta menemukan makna dalam bahan pembelajaran. Abstract conceptualization adalah konseptualisasi abstrak dimana siswa menciptakan teori-toeri untuk menjelaskan hasil dari pengamatan. Active Experimentation adalah siswa menggunakan teori untuk memecahkan masalah dan membuat keputusan (Schoenfeld, 2014).

\section{KESIMPULAN}

E-Modul matakuliah Masalah Nilai Awal dan Syarat Batas menggunakan pendekatan Experiential Learning terbukti valid, praktis, dan memiliki efek potensial tehadap kemampuan penalaran matematis mahasiswa. Hasil penelitian menunjukkan bahwa E-Modul telah valid dari kualitas materi maupun kualitas media dengan kriteria sangat valid, berdasarkan komentar ahli pada tahapan expert review dan one-to-one. Selanjutnya, implementasi E-Modul pada tahap small group dan field test menunjukkan kepraktisan E-Modul dengan kriteria praktis. Pengembangan E-Modul berbasis Experiential Learning yang menerapkan soal matematika yang non rutin dapat memberi efek potensial terhadap peningkatan kemampuan penalaran matematika mahasiswa pada matakuliah MNASB. Sarannya agar para dosen mulai membiasakan para mahasiswa untuk menyelesaikan soalsoal dengan tipe non rutin yang berorientasi pada kemampuan penalaran matematis mahasiswa.

\section{UCAPAN TERIMA KASIH}

Artikel ini merupakan publikasi hasil penelitian dengan skema penelitian Bidang Ilmu Tahun 2021 menggunakan dana yang bersumber dari DIPA Universitas Riau (UNRI). Oleh karena itu penulis mengucapkan terimakasih yang tak terhingga kepada pimpinan LPPM UNRI dan pimpinan UNRI 
Pengembangan E-Modul Matakuliah Masalah Nilai Awal Syarat Batas Berbasis Experiential Learning untuk

atas dukungan pendanaannya demi kesuksesan penelitian ini.

\section{REFERENSI}

Badu, S. Q. (2013). Implementasi evaluasi model kirkpatrick pada perkuliahan masalah nilai awal dan syarat batas. Jurnal Penelitian Dan Evaluasi Pendidikan, 16, 102-129. https://doi.org/10.21831/pep.v16i0.1108

Borland, K. W. (2000). Student development in college: Theory, research, and practice (review). The Journal of General Education, 49(3), 231-234. https://doi.org/10.1353/jge.2000.0018

Creswell, W. John \& Creswell, J. D. (2018). Research design: Qualitative, quantitative and mixed methods approaches (Fifth Edit). Sage Publication, Inc.

Elmunsyah, H., Prasetyo, D., \& Prihanto, D. (2018). Pengembangan media pembelajaran trainer jaringan LAN untuk mata pelajaran jaringan dasar pada paket keahlian TKJ kelas X di SMKN 2 Bojonegoro. Prosiding - Seminar Nasional Teknik Elektro UIN Sunan Gunung Djati Bandung, November, $143-156$. https://senter.ee.uinsgd.ac.id/repositori/index.php/prosiding/article/view/senter2016p17

Erawanto, U., \& Santoso, E. (2016). Pengembangan modul pembelajaran berbasis masalah untuk membantu meningkatkan berfikir kreatif mahasiswa. JINoP (Jurnal Inovasi Pembelajaran), 2(2), 427-436. https://doi.org/10.22219/jinop.v2i2.2629

Festiawan, R. (2020). Belajar dan pendekatan pembelajaran. 2020, 1-17. https://osf.io/mpng9/download

Habibatul Izzah, K., \& Azizah, M. (2019). Analisis kemampuan penalaran siswa dalam pemecahan masalah matematika siswa kelas IV. Indonesian Journal of Educational Research and Review, 2(2), 210-218. https://doi.org/10.23887/ijerr.v2i2.17629

Kolb, D. A. (1984). Experiential learning: Experience as the source of learning and development. Prentice Hall, Inc. https://doi.org/10.1016/B978-0-7506-7223-8.50017-4

Lubis, E. A., Napitupulu, E., \& Nugrahadi, E. W. (2020). Pengembangan modul berbasis experiential learning pada matakuliah perencanaan pembelajaran akuntansi. Jurnal Teknologi Informasi \& Komunikasi Dalam Pendidikan, 7(2), 146. https://doi.org/10.24114/jtikp.v7i2.23242

McKenney, S. E., \& Reeves, T. C. (2012). Conducting educational design research. Routledge.

Molas-Gallart, J., Boni, A., Giachi, S., \& Schot, J. (2021). A formative approach to the evaluation of transformative innovation policies. Research Evaluation, 30(4), 431-442. https://doi.org/10.1093/reseval/rvab016

Nurmeidina, R., Lazwardi, A., \& Ariyanti, I. (2020). Pengembangan modul teori peluang untuk meningkatkan hasil belajar dan disposisi matematis. Aksioma: Jurnal Program Studi Pendidikan Matematika, 9(2), 440-450. https://doi.org/10.24127/ajpm.v9i2.2824

Pamungkas, A. S., \& Yuhana, Y. (2016). Pengembangan bahan ajar untuk meningkatkan. JPPM, 9(2), $177-182$.

Pratiwi, K., Bahri, S., \& Pratiwi, D. D. (2021). Kemampuan penalaran matematis siswa berdasarkan gender dengan pendekatan STEM pada modul matematika. JRPM (Jurnal Review Pembelajaran Matematika), 6(1), 39-51. https://doi.org/10.15642/jrpm.2021.6.1.39-51 
Schoenfeld, A. H. (2014). Expert and novice mathematical problem solving. Journal for Research in Mathematics Education, 13(1), 256-267. Retrieved from https://eric.ed.gov/?id=ED.

Sholihah, D. A., \& Mahmudi, A. (2015). Keefektifan experiential learning pembelajaran matematika mts materi bangun ruang sisi datar. Jurnal Riset Pendidikan Matematika, 2(2), 175-185. https://doi.org/10.21831/jrpm.v2i2.7332

Smith, S., \& Kabele, J. (2020). Political discourse and mobility of worlds: Arguments for methodological narrativelinstitutional dualism. Social Science Information, 59(4), 604-631. https://doi.org/10.1177/0539018420977019

Suanto, E., Armis, A., \& Suhermi, S. (2020). Pengembangan bahan ajar matematika berazaskan experiential learning untuk meningkatkan kemahiran berpikir tingkat tinggi siswa SMP. Jurnal Cendekia: Jurnal Pendidikan Matematika, 4(2), 1300-1310. https://doi.org/10.31004/cendekia.v4i2.365

Suanto, E., Armis, A., Suhermi, S., \& Sari, A. (2017). Skema penelitian unggulan FKIP (Issue November). https://fkip.unri.ac.id/wp-content/uploads/2021/02/Laporan-Pengembangan-BahanAjar-Berbasis-Kompetensi-Pada-Mata-Kuliah-Masalah-Nilai-Awal-Dan-Syarat-Batas-DiProgam-Studi-Pendidikan-Matematika-Jurusan-PMIPA-FKIP-Universitas-Riau-1.pdf

Sugiharni, G. A. D. (2018). Pengembangan modul matematika diskrit berbentuk digital dengan pola pendistribusian asynchronous menggunakan teknologi open source. Jurnal Nasional Pendidikan Teknik Informatika (JANAPATI), 7(1), 58-72. https://doi.org/10.23887/janapati.v7i1.12667

Sugiyono. (2007). Statistik untuk penelitian. Alfabeta.

Sunendar, A. (2016). Mengembangkan disposisi matematik melalui model pembelajaran kontekstual. Jurnal THEOREMS, 1(1), 1-9.

Suryaningrat, E. F., Muslihah, N. N., Pujiasti, D. A., \& Adiredja, R. K. (2021). The influence of lectora inspire-based interactive learning media on students' learning motivation and mathematical reasoning abilities in primary schools. Journal of Physics: Conference Series, 1987(1), 0-7. https://doi.org/10.1088/1742-6596/1987/1/012035

Wahyuni, L. (2019). Kontribusi kemampuan awal dan minat mahasiswa terhadap hasil belajar mata kuliah masalah nilai awal syarat batas STKIP Muhammadiyah Sungai Penuh. Jurnal Lemma, 6(1), 1-7. https://doi.org/10.22202/j1.2019.v6i1.3245. 